\title{
Metastatic Sarcomatoid Renal Cell Carcinoma
}

National Cancer Institute

\section{Source}

National Cancer Institute. Metastatic Sarcomatoid Renal Cell Carcinoma. NCI Thesaurus.

Code C157757.

Sarcomatoid renal cell carcinoma that has spread to another anatomical site. 